\title{
High-rate deposition of microcrystalline silicon in a large-area PECVD reactor and integration in tandem solar cells
}

\author{
Gaetano Parascandolo*, Grégory Bugnon, Andrea Feltrin and Christophe Ballif \\ Ecole Polytechnique Fédérale de Lausanne (EPFL), Institute of Microengineering IMT, Photovoltaics and Thin Film Electronics \\ Laboratory, Rue A.-L. Breguet 2, CH-2000, Neuchâtel, Switzerland
}

\begin{abstract}
We study the high-rate deposition of microcrystalline silicon in a large-area plasma-enhanced chemical-vapor-deposition (PECVD) reactor operated at $40.68 \mathrm{MHz}$, in the little-explored process conditions of high-pressure and high-silane concentration and depletion. Due to the long gas residence time in this process, the silane gas is efficiently depleted using moderate feed-in power density, thus facilitating up-scaling of the process to large surfaces. As observed in more traditional deposition processes, the deposition rate and performance of device-quality material are limited by the inter-electrode gap of the reactor. We significantly increase the cell performances by reducing this gap. X-ray diffractometry (XRD) and secondary ion mass spectroscopy (SIMS) are used to characterize the microcrystalline material deposited in the modified reactor at a rate of $1 \mathrm{~nm} / \mathrm{s}$. Comparison with a microcrystalline process at a low deposition rate demonstrates that the crystallographic orientation of the absorbing layer of the cell and the concentrations of contaminants are strongly correlated and dependent on the process. We use microcrystalline cells with absorber layer grown at a rate of $1 \mathrm{~nm} / \mathrm{s}$ integrated as bottom cells in amorphous-microcrystalline (micromorph) tandem solar cells using the superstrate configuration. We report an initial efficiency of $10.8 \%$ (9.6\% stabilized) for a tandem cell with $1.2 \mathrm{~cm}^{2}$ surface. Copyright (C) 2010 John Wiley \& Sons, Ltd.
\end{abstract}

KEYWORDS

microcrystalline silicon; PECVD; high-rate deposition; material characterization; micromorph tandem

${ }^{*}$ Correspondence

Gaetano Parascandolo, Ecole Polytechnique Fédérale de Lausanne (EPFL), Institute of Microengineering IMT, Photovoltaics and Thin Film Electronics Laboratory, Rue A.-L. Breguet 2, CH-2000, Neuchâtel, Switzerland.

E-mail: gaetano.parascandolo@epfl.ch

Received 1 July 2009; Revised 20 November 2009

\section{INTRODUCTION}

Since the 1970's, the photovoltaic (PV) properties of semiconductor thin-films have been the subject of intense study by both academia and industry because of the potential reductions in cost of production of thinfilms compared to traditional PV technologies. In fact, the drastic reduction of utilization of raw material and the development of low-cost production processes on large areas have successfully shown that, despite lower efficiencies, thin-films are competitive alternatives to crystalline and polycrystalline silicon PV technologies. As a result, in 2008, thin-films represented $10 \%$ of entire $\mathrm{PV}$ production. At the current rate of growth, that level may realistically rise to $25-30 \%$ in the near future [1]. Among all the thin-film technologies for 2008, the most dominant technologies use amorphous silicon (a-Si:H) and cadmium-telluride (CdTe) representing a market share of 4 and 5\%, respectively. In February 2009, the biggest manufacturer of CdTe solar modules, First Solar, announced that it had reduced its manufacturing cost of solar modules to $0.98 \$$ per watt peak [2]. Cadmiumtelluride has a direct bandgap of $1.45 \mathrm{eV}$, which yields high module performances with single-junction devices (record module efficiency $\eta=10.7 \%$ [3]). Amorphous silicon single-junction commercial modules have stable efficiencies of about 6-7\% [4]. The main cause for a lower PV performance is light-induced degradation of a-Si:H [5]. Nevertheless, thin-film silicon-based multi-junction structures, such as tandem cells combining a-Si:H and microcrystalline silicon ( $\mu c-\mathrm{Si}: \mathrm{H})$ [6,7] materials, have the potential to achieve a stable module performance over 
$10 \%$. In the following, we use the term "tandem" to refer to amorphous-microcrystalline multi-junction devices. Amorphous and microcrystalline silicon have bandgaps of 1.75 and $1.1 \mathrm{eV}$, respectively. According to semiempirical calculations, this combination of bandgaps corresponds to the optimum for achieving high efficiencies in tandem structures [8]. However, $\mu \mathrm{c}-\mathrm{Si}: \mathrm{H}$ has an indirect bandgap and even if light-trapping techniques are used, a thick absorber i-layer $(\sim 2 \mu \mathrm{m})$ is needed for efficient absorption of red and infrared light. Thus, high-rate deposition of $\mu \mathrm{c}-\mathrm{Si}: \mathrm{H}$ is the most important technological issue with respect to low-cost manufacturing of highefficiency silicon-based thin-film solar cells. In Reference [9], Figure 1 summarizes all data found in the literature about high-rate deposition of $\mu \mathrm{c}-\mathrm{Si}: \mathrm{H}$ in plasma-enhanced chemical-vapor-deposition (PECVD). A systematic increase of the deposition rate of device grade $\mu \mathrm{c}-\mathrm{Si}: \mathrm{H}$ is achieved by increasing the excitation frequency from radio frequency (RF) to very-high-frequency (VHF), and passing from lowto high-pressure depletion processes (LPD to HPD). These modifications satisfy two requirements for high-quality $\mu \mathrm{c}-\mathrm{Si}: \mathrm{H}$ : reducing the detrimental ion bombardment of the growing surface and ensuring efficient utilization of precursor gases and film uniformity [10-13]. Using HPD process conditions, efficiencies as high as 9.8 [14] and $9.13 \%$ [15] were achieved with deposition rates of 11 and $23 \AA / s$, respectively. Study [16] describes $\mu \mathrm{c}-\mathrm{Si}: \mathrm{H}$ and tandem cells with $\eta=8.5 \%$ at $31 \AA / \mathrm{s}$ and initial $\eta=13.5 \%$ at $14 \AA / \mathrm{s}$, respectively. A number of other studies also report on further increases of the deposition rates $[12,17$ 20]. These results are achieved in small-area reactors using process conditions of high input gas flow and HPD where high depletion is achieved using high feed-in power density. The scaling to large areas of such high-rate deposition processes requires a complex design of the reactor to preserve film uniformity. At the IPV Forschungszentrum Jülich, $\mu \mathrm{c}-\mathrm{Si}: \mathrm{H}$ cells $\left(1 \mathrm{~cm}^{2}\right)$ were deposited in a modified reactor with a $30 \times 30 \mathrm{~cm}^{2}$ substrate carrier area and achieved efficiencies of $9.4 \%$ at rate of $5 \AA / \mathrm{s}$, using RF excitation [21], 9.2\% at $10 \AA / \mathrm{s}$ and $7.9 \%$ at $20 \AA / \mathrm{s}$, using VHF [13]. Using a larger reactor $\left(138 \times 74 \mathrm{~cm}^{2}\right.$ substrate carrier area), they also reported an average initial aperture area efficiency higher than $10 \%$ for tandem mini-modules $\left(10 \times 10 \mathrm{~cm}^{2}\right.$ and $\left.30 \times 30 \mathrm{~cm}^{2}\right)$ deposited at $5 \AA / \mathrm{s}$, using RF [21]. Sanyo achieved an average efficiency of $9.8 \%$ at $15 \AA / \mathrm{s} \quad\left(1 \mathrm{~cm}^{2}\right.$ cells, maximum $\eta=10.5 \%$ ) on a $55 \times 65 \mathrm{~cm}^{2}$ substrate, using a multi-hollow cathode [22]. Mitsubishi Heavy Industries reported an $11 \%$ initial efficiency on a mini-module of $40 \times 50 \mathrm{~cm}^{2}$ and ongoing studies for high deposition rates on $1.4 \times 1.1 \mathrm{~m}^{2}$ area, using a ladder shaped electrode [23]. Kaneka Corporation reported an average initial tandem module $\left(91 \times 45.5 \mathrm{~cm}^{2}\right)$ efficiency of $11 \%$ (maximum $11.6 \%$ ) on long-run (over 4000 modules) production processes at rates up to $11 \AA$ /s [24].

In this work we develop a VHF-PECVD process using low total gas flow, low $\mathrm{SiH}_{4}$ dilution, and relatively low feed-in power density to achieve high-rate deposition of $\mu \mathrm{c}-\mathrm{Si}: \mathrm{H}$ cells in a simple parallel-plate capacitive reactor. By maintaining a high-pressure environment, we increase the residence time of precursor gases, enabling efficient dissociation of $\mathrm{SiH}_{4}$ at a low power density and deposition of the $\mu \mathrm{c}-\mathrm{Si}: \mathrm{H}$ film at high-rate. The development of such a process is applicable to low-cost industrial development. Our study is performed in a semi-industrial large-area $\mathrm{R} \& \mathrm{D}$ reactor, allowing extrapolation to the industrial scale.

\section{EXPERIMENTAL}

Microcrystalline silicon cells were deposited by VHFPECVD in a large area R\&D parallel plate single chamber reactor operated at $40 \mathrm{MHz}$ (KAI-M in the following). The reactor was designed and built in-house according to the KAI concept described in detail in Reference [25]. The reactor is based on a plasma box PECVD chamber [26] equipped with differential pumping, enabling CVD growth of high purity material. Our plasma box [27], originally designed with a standard inter-electrode distance (or gap) of $25 \mathrm{~mm}$, was modified in house to reduce the gap to $13 \mathrm{~mm}$. The powered electrode area is $50 \times 60 \mathrm{~cm}^{2}$. Using a p-i-n configuration and a deposition rate of $10 \AA / s$, we deposited $\mu \mathrm{c}-\mathrm{Si}: \mathrm{H}$ cells for single junctions and as bottom cells for tandem devices. We compared single-junction cells with the best cells deposited, in our laboratory, at the same rate in a similar KAI reactor (KAI-S), where the inter-electrode gap was not modified from the standard value. The absorbing i-layer thickness of the $\mu \mathrm{c}-\mathrm{Si}: \mathrm{H}$ cell was $1.2 \mu \mathrm{m}$ in single-junctions and $1.8 \mu \mathrm{m}$ in tandems. The substrate used was Schott AF45 glass with a highly transparent conductive oxide (TCO) comprised of zincoxide $(\mathrm{ZnO})$ as a front electric contact and window layer deposited in-house by low-pressure CVD (LPCVD) [28]. The rough $\mathrm{ZnO}$ film is randomly textured and its surface is characterized by pyramidal structures. The size and shape of these features can be controlled by changing the LPCVD deposition parameters [29] or by post-deposition surface treatment [30]. By changing the grain size, the light scattering properties of the front TCO can be adjusted to optimally fit the requirement of the desired cell (a-Si, $\mu \mathrm{c}-\mathrm{Si}: \mathrm{H}$ or tandem). The pyramidal structures in the $\mathrm{ZnO}$ layer can be smoothed to reduce the formation of cracks in the $\mu \mathrm{c}-\mathrm{Si}: \mathrm{H}$ cell, which can lead to low open circuit voltage $\left(V_{\mathrm{oc}}\right)$ and fill factor (FF) [31]. We used a similar $\mathrm{ZnO}$ film as back electric contact and optical reflector in combination with white paint. The device area was defined via lift-off structuring and the nominal values used were $0.25 \mathrm{~cm}^{2}$ for single-junction and $1.2 \mathrm{~cm}^{2}$ for multi-junction cells. These values correspond to the device aperture and active area. The external quantum efficiency (EQE) was measured with a spectral response setup under short circuit conditions. We calculated the short circuit current density $\left(J_{\mathrm{sc}}\right)$ by integrating the product of the EQE (measured without voltage bias) and the photon flux corresponding to the AM $1.5 \mathrm{~g}$ solar spectrum over the wavelength range. The integral multiplied by the electron charge is $J_{\mathrm{sc}}$. The 
current density-voltage (JV) measurements were performed with a class A AM $1.5 \mathrm{~g}$ sun simulator at standard conditions (Wacom, $25^{\circ} \mathrm{C}, 100 \mathrm{~mW} / \mathrm{cm}^{2}$ ). The $V_{\text {oc }}$ and FF were obtained from the JV curve and the current densities were normalized with the $J_{\mathrm{sc}}$ value obtained from the EQE measurement. This method avoids uncertainties in the determination of the solar cell surface area.

\section{PROCESS CONDITIONS FOR $\mu \mathrm{C}-S \mathrm{i}: \mathrm{H}$ DEPOSITION AT $10 \mathrm{~A} / \mathrm{s}$}

The amorphous to crystalline ratio of PECVD grown $\mu \mathrm{c}-\mathrm{Si}: \mathrm{H}$ films can be adjusted by varying deposition parameters such as gas flows, total pressure, and power input. The best performances of $\mu \mathrm{c}-\mathrm{Si}: \mathrm{H}$ solar cells are obtained at the so-called amorphous-to-microcrystalline transition. Microcrystalline silicon structure consists of nanocrystals whose sizes range from a few nanometers to tens of nanometers, embedded into an a-Si:H matrix. These nanocrystals form conglomerates and columnar structures with sizes on the order of micrometers as TEM measurements by several groups shown (e.g., Figure 2 in Reference [32]). One can refer to this material both as nano- or microcrystalline. For the purposes of this study, we will use the term microcrystalline. The mechanisms involved in the deposition of $\mu \mathrm{c}-\mathrm{Si}: \mathrm{H}$ are complex and not completely understood, however there is a general consensus on the key role of atomic hydrogen in the crystallization of the growing film [33-36]. So far, most efforts have been devoted to the development of PECVD processes at low silane $\left(\mathrm{SiH}_{4}\right)$ concentration, on the order of a few percent of the total gas mixture. A major drawback of this method is that high-rate growth of the $\mu \mathrm{c}-\mathrm{Si}: \mathrm{H}$ i-layer requires a high hydrogen flow, especially in largearea reactors used for industrial production. A large total gas flow rate results in a short residence time and a very high feed-in VHF power density is needed to efficiently deplete $\mathrm{SiH}_{4}$. These conditions can lead to damage in the top a-Si cell layer from excessive heat, making the process not scalable to the industrial level.

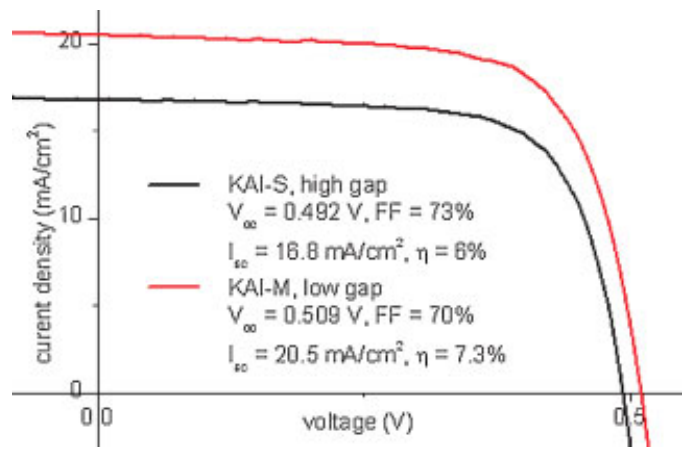

Figure 1. JV curves of the best high-rate $\mu \mathrm{c}-\mathrm{Si}: \mathrm{H}$ cells deposited so far in our standard (black line) and reduced-gap (red line) KAI reactors.

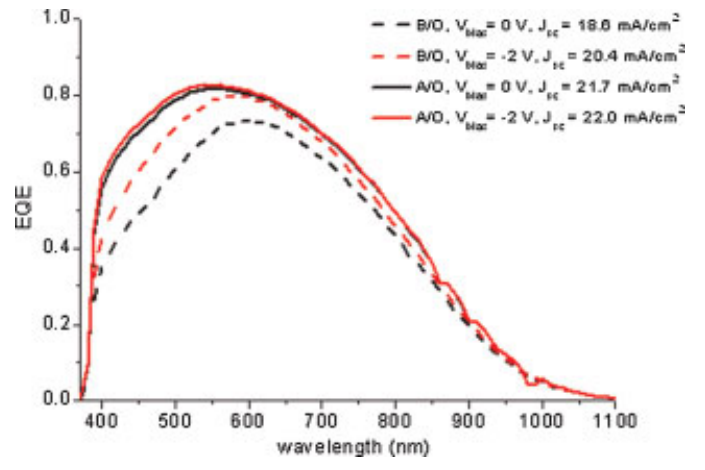

Figure 2. EQE of $\mu \mathrm{c}-\mathrm{Si}: \mathrm{H}$ solar cells deposited before $(\mathrm{B} / \mathrm{O}$ dashed lines) and after the optimization ( $\mathrm{A} / \mathrm{O}$, full lines) of the $\mathrm{p}-\mathrm{i}$ interface. Black lines correspond to measures performed without bias voltage, while red lines are obtained using a $-2 \mathrm{~V}$ reverse bias.

It has recently been shown [37] that the deposition of $\mu c-S i: H$ material at the amorphous-to-microcrystalline transition is not only related to the input $\mathrm{SiH}_{4}$ concentration $c$, but rather to the $\mathrm{SiH}_{4}$ concentration in the plasma $c_{\mathrm{p}}=c(1-D)\left(D\right.$ is the fractional $\mathrm{SiH}_{4}$ depletion). Low values of $c_{\mathrm{p}}$, resulting in microcrystalline growth, can be achieved at arbitrarily high input $\mathrm{SiH}_{4}$ concentration [38]. provided $D$ is large enough. $\mathrm{SiH}_{4}$ can be efficiently dissociated either by increasing the feed-in power density or the residence time of the gases. The first approach is the one traditionally adopted, as we have recalled in our introduction. In this case, particular care must be taken in order to avoid damage related to ion bombardment on the growing surface or heating of the substrate. In the second approach, long residence time of $\mathrm{SiH}_{4}$ gas is achieved by reducing the dilution in hydrogen $\left(\mathrm{H}_{2}\right)$ and increasing working pressure, so that $\mathrm{SiH}_{4}$ can be efficiently dissociated using lower power densities. In fact, since the residence time is proportional to the pressure and to the inverse of the total gas flow, for a given pressure and $\mathrm{SiH}_{4}$ flow rate, the residence time will be roughly one order of magnitude longer when the $\mathrm{H}_{2}$ dilution is divided by ten. In the present work, we explore such a high-pressure and high-silane concentration and depletion deposition process. With $\mathrm{SiH}_{4}$ input concentrations up to $18 \%$, we achieve sufficient $\mathrm{SiH}_{4}$ dissociation to grow the $\mu \mathrm{c}-\mathrm{Si}: \mathrm{H}$ i-layer at $1 \mathrm{~nm} / \mathrm{s}$. For this we used a moderate total flow rate and input power densities between 0.25 and $0.35 \mathrm{~W} / \mathrm{cm}^{2}$, and a pressure of a few mbar, taking advantage of residence times on the order of a second. Extensive studies of this regime were performed in our KAI-S reactor with $25 \mathrm{~mm}$ standard inter-electrode gap [39]. The highest efficiency reported for a $\mu \mathrm{c}-\mathrm{Si}: \mathrm{H}$ single-junction cell deposited at rates as high as $1 \mathrm{~nm} / \mathrm{s}$ is $\eta=6 \%$ with $V_{\mathrm{oc}}=0.492 \mathrm{~V}$, $\mathrm{FF}=73 \%, J_{\mathrm{sc}}=16.8 \mathrm{~mA} / \mathrm{cm}^{2}[40]$. FTPS measures performed on samples deposed in KAI-S when working in processes characterized by powder formation reveal defective material [39]. The defects are likely related to the incorporation of large powder-conglomerates in the 
film. Moreover, powders are responsible for non-uniform deposition [41] and plasma-time instability [42].

Powder is produced during PECVD processes when silane radicals react in the gas phase instead of reacting at the electrode surfaces [41]. If the surface to volume ratio of the reactor is increased, the probability of a silane radical contributing to film growth, rather than creating powder by interacting in the gas phase, increases. In a parallel plate reactor, the surface to volume ratio scales as $2 / d_{\text {gap }}\left(d_{\text {gap }}\right.$ is the inter-electrode distance; for simplicity, we are neglecting the lateral surface walls for a large-area and small-gap reactor). Powder formation, and the following coagulation [41] leading to large size powder particles, can be reduced using a smaller $d_{\text {gap }}$ by means of this simple geometric adjustment. Reducing the inter-electrode gap, it is then possible to work at higher pressure without producing powders. In this way, film homogeneity [13] and quality [16] are improved, and eventually detrimental ion bombardment at the growing $\mu \mathrm{c}-\mathrm{Si}: \mathrm{H}$ surface is reduced as an effect of the high process pressure. Moreover, at high pressure, a small inter-electrode gap allows a stable plasma discharge to be maintained at lower power densities [14].

The inter-electrode distance of our KAI-M reactor was then reduced to $13 \mathrm{~mm}$ and PECVD processes were developed at higher pressure. The improvement of the cell performance reflects the improved material quality. So far, the highest efficiency of a $\mu \mathrm{c}-\mathrm{Si}: \mathrm{H}$ cell grown at $1 \mathrm{~nm} / \mathrm{s}$ is $\eta=7.3 \%$ with $V_{\mathrm{oc}}=0.509 \mathrm{~V}, \mathrm{FF}=70 \%, J_{\mathrm{sc}}=20.5 \mathrm{~mA} /$ $\mathrm{cm}^{2}$. High-rate deposition was achieved, in this case, with a feed-in power density of $0.28 \mathrm{~W} / \mathrm{cm}^{2}$. This result can be compared to those in [13] where power densities between 0.6 and $1.1 \mathrm{~W} / \mathrm{cm}^{2}$ were used to deposit device-quality $\mu \mathrm{c}$-Si:H material at rates between 10 and $20 \AA$ /s. In Figure 1, we compare the JV curve of the best high-rate KAI-M cell to results reported in [40]. EQE measurements show that the increase in short circuit current is a result of a better spectral response over the whole spectral range (not shown).

To achieve these results, a significant effort was devoted to the optimization of the interface between the p- and i-layer, using a single-chamber process. In Figure 2, the $\mathrm{EQE}$ measurement before optimization (B/O) shows low spectral response to blue light. Comparing measurements performed at zero and reverse bias $(-2 \mathrm{~V})$ shows bad carrier collection for the same spectral range. These EQE features are most likely related to boron contamination of the absorbing layer. Etching of the pdoped film can occur at the breakdown of the H-rich ilayer plasma even at moderate VHF power densities, resulting in boron contamination of the i-layer. To prevent boron incorporation or diffusion into the i-layer, following deposition of the p-layer we moved the substrate to the reactor load-lock and performed an etch plasma cleaning of the deposition chamber. Then, a surface treatment of the p-doped substrate created a thin oxide layer on the film that increased the $V_{\mathrm{oc}}$ and the FF of the cell. Finally, a low substrate etching was achieved by starting the $\mu \mathrm{c}-\mathrm{Si}: \mathrm{H}$ i-layer deposition with low feed-in power densities. The $\mathrm{SiH}_{4}$ gas flow must be kept low as well, in order to ensure the crystallinity of the film. After a deposition of about $50 \mathrm{~nm}$ of $\mu \mathrm{c}-\mathrm{Si}: \mathrm{H}$ material in these conditions, a step-like increase of $\mathrm{SiH}_{4}$ flow and feed-in power density was performed without stopping the plasma or changing the other plasma parameters, raising the deposition rate to $10 \AA / \mathrm{s}$. EQE measurement of high-rate $\mu \mathrm{c}-\mathrm{Si}: \mathrm{H}$ cells before and after $(\mathrm{A} / \mathrm{O}) \mathrm{p}-\mathrm{i}$ interface optimization are compared in Figure 2. The satisfactory improvement of the $\mathrm{p}-\mathrm{i}$ interface results in the enhancement of cell performances shown in this section. At present, we can turn our efforts to the exploration of a wide range of plasma parameters for the optimization of the high-rate deposition of $\mu \mathrm{c}-\mathrm{Si}: \mathrm{H}$ i-layers. In situ plasma monitoring based on the diagnostic setup recently developed at the Institute of Microtechnology in Neuchâtel [43] will be used to improve the understanding of the deposition process under study.

\section{SIMS AND XRD MATERIAL STUDY}

Material quality was studied via secondary ion mass spectroscopy (SIMS) and X-ray diffractometry (XRD). We compare our $\mu \mathrm{c}-\mathrm{Si}: \mathrm{H}$ cells deposited at $1 \mathrm{~nm} / \mathrm{s}$ with the best cell developed so far in our KAI-M reactor at low deposition rate. The i-layer of the latter was deposited at a rate of $4.3 \AA / \mathrm{s}$ in a regime of higher dilution, with $5.5 \%$ of $\mathrm{SiH}_{4}$ in the gas mixture. The cell efficiency was $\eta=8.1 \%$ with $V_{\mathrm{oc}}=0.511 \mathrm{~V}, \mathrm{FF}=73 \%$, and $J_{\mathrm{sc}}=21.9 \mathrm{~mA} / \mathrm{cm}^{2}$. It has been proposed [44] that nitrogen $(\mathrm{N})$ or oxygen $(\mathrm{O})$ contents of $7 \cdot 10^{18}$ or $2 \cdot 10^{19}$ atoms $/ \mathrm{cm}^{3}$, respectively, constitute a threshold value above which the collection efficiency (spectral response and FF) of $\mu \mathrm{c}-\mathrm{Si}: \mathrm{H}$ for red and infrared illumination drops dramatically. This decrease is due to the n-doping character of these two elements. The physical relation between the doping of the i-layer and the drop of optical and electrical performances of the device is found in the modified band energy structure of the p-i-n junction. Doping increases the density of recombination centers and modifies the profile of the electric field in the junction, resulting in reduced collection efficiency [45]. Nevertheless, many hypotheses about the actual electronic structure of a $\mu \mathrm{c}-\mathrm{Si}: \mathrm{H}$ p-i-n device can be made. The charge transport mechanism in $\mu \mathrm{c}-\mathrm{Si}: \mathrm{H}$ is still a controversial subject. A simple intuitive picture of the mechanism involved is as follows: collection of electronhole pairs generated by blue light at the interface between the $\mathrm{p}$ - and i-layer takes place independently of the $\mathrm{O}$ concentration in the i-layer. On the other hand, holes generated by red and infrared light in the i-layer volume recombine with excess electrons while traveling toward the front electrode, resulting in reduced $J_{\text {sc }}$ and FF.

SIMS measures in Figure 3 show that the concentration profile of contaminants is almost constant across the i-layers of both our cells. $\mathrm{N}$ contents are comparable and below the threshold for both, while $\mathrm{O}$ contents are $<2 \cdot 10^{19}$ and $5 \cdot 10^{19}$ atoms $/ \mathrm{cm}^{3}$ in i-layers grown at low- and high-rate, respectively. In Figure 4, the EQE of the two cells are 


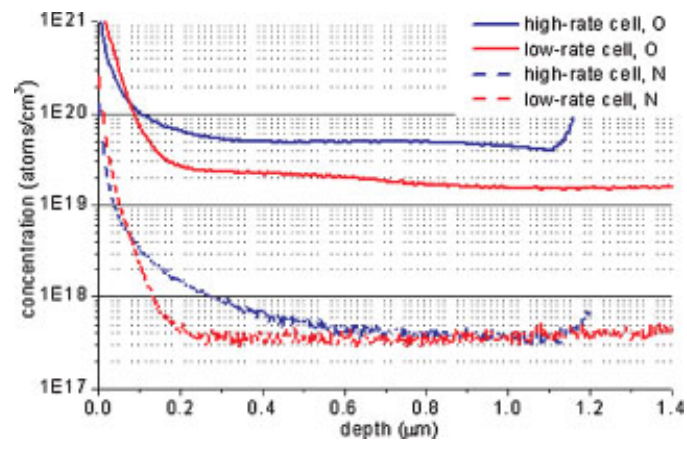

Figure 3. Oxygen (full lines) and nitrogen (dotted lines) concentration profile in high- (blue lines) and low-rate (red lines) grown $\mu \mathrm{c}-\mathrm{Si}$ :H i-layers from SIMS measures. Films are grown on rough TCO.

compared. As expected, the high $\mathrm{O}$ content in the high-rate cell results in a drop of response to long wavelengths.

XRD spectra were measured on rough TCO substrates, in order to reproduce the crystalline structure in the devices [46]. In Figure 5, the spectra indicate that the intensity ratio of the (220) to (111) crystallographic orientation peaks for the high-rate deposited film is almost two times smaller than for the low-rate deposited one. The short circuit current density of the high-rate deposited cell is smaller than the $J_{\mathrm{sc}}$ measured in the low-rate deposited cell. According to Reference [32], preferential (220) orientation is associated to the growth of dense material at the amorphous-to-microcrystalline transition and to better cell performances. Consequently, the observed reduction in $J_{\mathrm{sc}}$ could be explained in terms of a random orientation of the micro-crystals in the film deposited at high-rate. Postdeposition contamination related to the random and less dense $\mu \mathrm{c}-\mathrm{Si}: \mathrm{H}$ structure seen in the XRD spectra and is a possible explanation of higher $\mathrm{O}$ content in the film deposited at high-rate $[15,32]$ measured by SIMS. Further analysis of the dependence of the $\mathrm{O}$ content and crystallographic orientation of films on deposition pressure

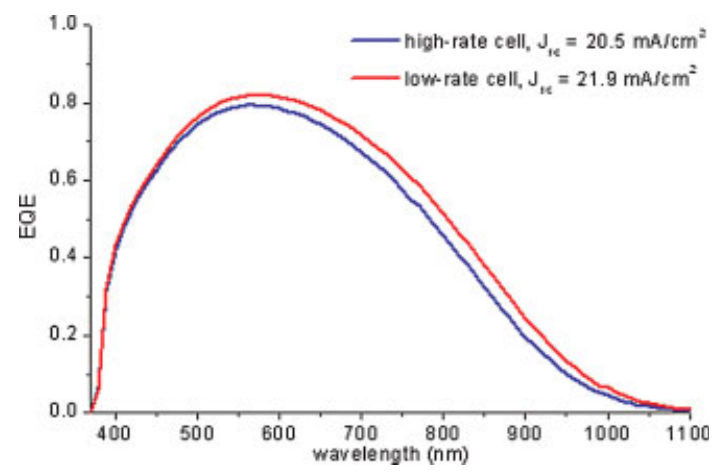

Figure 4. Comparison of the EQE of the best cells grown at low(blue line) and high-rate (red line) in KAI-M. Drop in the red and infrared response is due to the high $\mathrm{O}$ content of the high-rate grown cell.

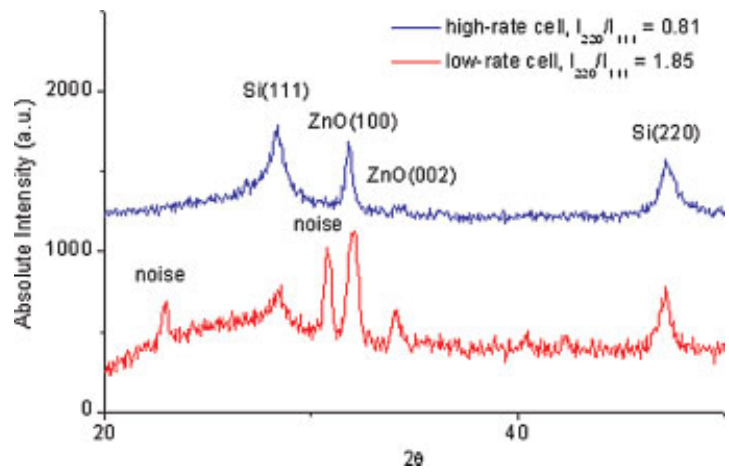

Figure 5. XRD spectra of high- (blue line) and low-rate (red line) grown $\mu \mathrm{c}$-Si:H i-layers. The two peaks at $2 \theta=28.494$ and $2 \theta=47.306$ correspond to the (111) and (220) crystal orientations of cubic Si. Peaks at $2 \theta=31.772$ and $2 \theta=34.420$ correspond to the (100) and (002) crystal orientations of hexagonal $\mathrm{ZnO}$ (TCO substrate). The two additional peaks observed in the red curve have been identified as noise in the measure.

and hydrogen flow will be used to optimize the high-rate deposition process of $\mu \mathrm{c}-\mathrm{Si}: \mathrm{H}$ material.

\section{TANDEM CELL}

Tandem solar cells in superstrate configuration were prepared with $\mu \mathrm{c}-\mathrm{Si}: \mathrm{H}$ i-layer bottom cells of $1.8 \mu \mathrm{m}$ thickness deposited at $1 \mathrm{~nm} / \mathrm{s}$. Top a-Si cells i-layers had a $220 \mathrm{~nm}$ thickness. So far, an initial efficiency $\eta=10.8 \%$ was achieved with $V_{o c}=1.37 \mathrm{~V}, \quad \mathrm{FF}=68 \%$, and $J_{\mathrm{sc}}=11.6 \mathrm{~mA} / \mathrm{cm}^{2}$ for a bottom-limited tandem cell. The standard procedure to degrade a-Si:H and tandem devices to a stable efficiency involves exposure to one sun light illumination at $50^{\circ} \mathrm{C}$, for $1000 \mathrm{~h}$ in open circuit voltage. After degradation, the efficiency of our tandem cell stabilized at $\eta=9.6 \%$, with $V_{\mathrm{oc}}=1.34 \mathrm{~V}, \mathrm{FF}=65 \%$, and $J_{\mathrm{sc}}=11 \mathrm{~mA} / \mathrm{cm}^{2}$, corresponding to a relative degradation of $11 \%$. The initial and stabilized EQE are compared in Figure 6. Note that the cell design allows good light

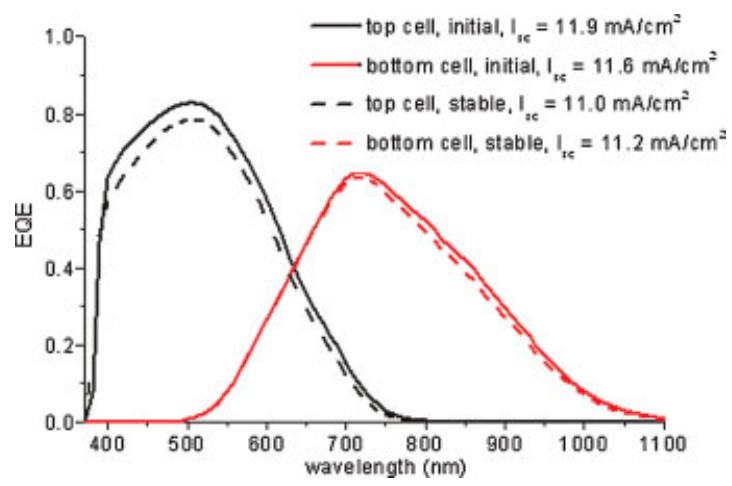

Figure 6. EQE of our best high-rate micromorph cell. A good current matching between the top and bottom cell is achieved with thicknesses of 220 and $1800 \mathrm{~nm}$, respectively. 
trapping management, so that the currents in the top and bottom cells are well matched.

To the best of our knowledge, our stabilized efficiency of $\eta=9.6 \%$ is among the highest conversion efficiencies achieved for tandem solar cells with a bottom cell deposited at high-rate $(1 \mathrm{~nm} / \mathrm{s})$ in a large-area parallel plate PECVD capacitive reactor, without the use of a modified cathode, such as multi-hollow [22] and laddershaped cathodes [23].

\section{CONCLUSION}

A high-pressure and high-silane concentration and depletion deposition process was used in a large-area capacitive reactor with small inter-electrode gap in order to achieve high-rate deposition of $\mu \mathrm{c}-\mathrm{Si}: \mathrm{H}$ under low-gasflow and low feed-in power input conditions. A process for $1 \mathrm{~nm} / \mathrm{s}$ deposition rate has been identified as a starting point for cell optimization. Preliminary material analysis suggests a relation between the microstructure and the impurity contents of the film. With this material, that is yet to be optimized, the best $\mu \mathrm{c}-\mathrm{Si}: \mathrm{H}$ single-junction cell efficiency achieved was $\eta=7.3 \%$. Furthermore, we deposited an amorphous-microcrystalline silicon tandem cell that yielded an initial efficiency of $\eta=10.8 \%$ and stabilized efficiency of $\eta=9.6 \%$, after light soaking. Careful cell design allowed us to achieve a good light management in the cell, resulting in a very satisfactory current matching between the top and the bottom cells. Optimization of the absorbing $\mu \mathrm{c}-\mathrm{Si}: \mathrm{H}$ i-layer is expected to lead to even higher tandem cell efficiency at high deposition rates.

\section{ACKNOWLEDGEMENTS}

This work was performed within the EU-Project "Athlet" under the contract 019670 .

\section{REFERENCES}

1. Jäger-Waldau A. PV STATUS Report 2008. Office for Official Publications of the European Communities 2008.

2. First Solar, Press Release 24 February 2009; Available at: http://investor.firstsolar.com/phoenix.zhtml?c=201491 $\& \mathrm{p}=$ irol-newsArticle $\& \mathrm{ID}=1259614 \&$ highlight $=$

3. Cunningham D, Davies K, Grammond L, Mopas E, O'Connor N, Rubcich M, Sadeghi M, Skinner D, Trumbly T. Large area Apollo ${ }^{\mathrm{TM}}$ module performance and reliability. Conference Record, 28th IEEE Photovoltaic Specialistic Conference, Alaska, September 2000; 13-18.

4. Tawada Y, Yamagishi H, Yamamoto K. Mass production of thin film silicon PV modules. Solar Energy Materials and Solar Cells 2003; 78: 647-662.
5. Staebler DL, Wronski CR. Reversible conductivity changes in discharge-produced amorphous Si. Applied Physics Letters 1977; 31: 292-294.

6. Meier J, Dubail S, Flückiger R, Fischer D, Keppner H, Shah A. Intrinsic microcrystalline silicon $(\mu \mathrm{c}-\mathrm{Si}: \mathrm{H})-$ a promising new thin film solar cell material. Proceedings of the 1st World WCPEC, 1994; 476-479.

7. Meier J, Torres P, Platz R, Dubail S, Kroll U, Anna Selvan JA, Pellaton-Vaucher N, Hof Ch, Fischer D, Keppner H, Shah A, Ufert K-D, Giannoulès P, Köler J. On the way towards high-efficiency thin film silicon solar cells by the "micromorph" concept. Proceedings of the MRS Symposium, Spring Meeting, San Francisco, 1996; 420: 3-14.

8. Shah AV, Vaněček M, Meier J, Meillaud F, Guillet J, Fischer D, Droz C, Niquille X, Faÿ S, Vallat-Suvain E, Terrazzoni-Daudrix V, Bailat J. Basic efficieny limits, recent experimental results and novel light-trapping schemes in a-Si:H, $\mu \mathrm{c}-\mathrm{Si}: \mathrm{H}$ and "micromorph tandem" solar cells. Journal of Non-Crystalline Solids 2004; 338-340: 639-645.

9. Smets AHM, Matsui T, Kondo M. High-rate deposition of microcrystalline silicon p-i-n solar cells in the high pressure depletion regime. Journal of Applied Physics 2008; 104: 034508.

10. Kroll U, Shah A, Keppner H, Meier J, Torres P, Fisher D. Potential of VHF-plasmas for low-cost production of a-Si:H solar cells. Solar Energy Materials and Solar Cells 1997; 48: 343-350.

11. Shah A, Torres P, Tscharner R, Wyrsch N, Keppner H. Photovoltaic technology: the case for thin-film solar cells. Science 1999; 285: 692-698.

12. Kondo M. Microcrystalline materials and cells deposited by RF glow discharge. Solar Energy Material \& Solar Cells 2003; 78: 543-566.

13. Kilper T, Repman T, Rech B, Bräuer G, Wieder S. Development of microcrystalline silicon solar cells using large area capacitively coupled planar electrodes. Proceedings of the 20th EU-PVSEC, 2005; 15441547.

14. Mai Y, Klein S, Carius R, Wolff J, Lamberz A, Finger F, Geng X. Microcrystalline silicon solar cells deposited at high rates. Journal of Applied Physics 2005; 97 : 114913.

15. Matsui T, Matsuda A, Kondo M. High efficiency and high-deposition-rate microcrystalline silicon p-i-n solar cells. Proceedings of the 19th EU-PVSEC, 2004; 407-1410.

16. Goya S, Nakano Y, Watanabe T, Yamashita N, Yonekura Y. The effect of narrow gap length on the highrate deposition of microcrystalline silicon. Proceedings of the 19th EU-PVSEC, 2004; 1625-1628.

17. Kondo M, Matsuda A. An approach to device grade amorphous and microcrystalline silicon fabricated at higher deposition rates. Current opinion in Solid State and Material Science 2002; 6: 445-453.

18. Rath JK, Verker A, Franken R, vas Bommel C, ven der Werf K, Gordijn A, Schropp R. Implementation of 
highly stable microcrystalline silicon by VHF PECVD at high deposition rate in micromorph tandem cells. Proceedings of the 4th World WCPEC, 2006; 1473 1476.

19. Niikura C, Itagaki N, Matsuda A. Guiding principles for obtaining high-quality microcrystalline silicon at high growth rates using $\mathrm{SiH} 4 / \mathrm{H} 2$ glow-discharge plasma. Japanese Journal of Applied Physics 2007; 46(5A): 3052-3058.

20. Sobajima Y, Nishino M, Fukumori T, Kurihara M, Higuchi T, Nakano S, Toyama T, Okamoto H. Solar cell of $6.3 \%$ efficiency employing high deposition rate $(8 \mathrm{~nm} / \mathrm{s})$ microcrystalline silicon photovoltaic layer. Solar Energy Materials and Solar Cells 2009; 93: 980-983.

21. Rech B, Repmann T, van den Donker MN, Berginski M, Kilper T, Hüpkes J, Calnan S, Stiebig H, Wieder S. Challenges in microcrystalline silicon based solar cell technology. Thin Solid Films 2006; 511-512: 548 555.

22. Kunii T, Murata K, Matsumoto M, Kawamoto K, Kobayashi Y, Aya Y, Nakagawa M, Terakawa A, Tanaka M. Efficient production technology for microcrystalline silicon solar cells using a localized plasma confinement (LPC) CVD method. Proceedings of the $33^{\text {rd }}$ IEEE, PVSC '08, 2008; 1-5.

23. Takatsuka H, Yamauchi Y, Takeuchi Y, Fukagawa M, Kawamura K, Goya S, Takano A. The world largest high efficiency thin film silicon solar cell module. Proceedings of the 4th World WCPEC, 2006; 2028 2033.

24. Yoshimi M, Sasaki T, Sawada T, Suezaki T, Meguro T, Matsuda T, Sato K, Wadano K, Ichikawa M, Nakajima A, Yamamoto K. High efficiency thin film silicon hybrid solar cell module on $1 \mathrm{~m}^{2}$-class large area substrate. Proceedings of the 3rd World WCPEC, 2003; 1566-1569.

25. Perrin J, Schmitt J, Hollenstein C, Howling A, Sansonnens L. The physics of plasma-enhances chemical vapor deposition for large area coating: industrial application to flat panel displays and solar cells. Plasma Physics and Controlled Fusion 2000; 42: B353-B363.

26. Bubenzer A, Schmitt JPM. Plasma processes under vacuum conditions. Vacuum 1990; 41: 1957-1961.

27. Shah A, Meier J, Buechel A, Kroll U, Steinhauser J, Meillaud F, Schade H, Dominé D. Towards very lowcost mass production of thin-film silicon photovoltaic (PV) solar modules on glass. Thin Film Solids 2006; 502: 292-299.

28. Dominé D, Buehlmann P, Bailat J, Billet A, Feltrin A, Ballif C. Optical management for high-efficiency thinfilm silicon micromorph solar cells with a in situ oxide based intermediate reflector. Rapid Research Letter 2008; 2: 163-165.

29. Faÿ S, Kroll U, Bucher C, Vallat-Sauvain E, Shah A. Low pressure chemical vapor deposition of $\mathrm{ZnO}$ layers for thin-film solar cells: temperature-induced morphological changes. Solar Energy Material \& Solar Cells 2005; 86: 385-397.

30. Bailat J, Dominé D, Schlüchter R, Steinhauser J, Faÿ S, Freitas F, Bücher C, Feitknecht L, Niquille X, Tscharner R, Shah A, Ballif C. High-efficiency p-i$\mathrm{n}$ microcrystalline and micromorph thin film silicon solar cells deposited on LPCVD $\mathrm{ZnO}$ coated glass substrates. Proceedings of the 4th World WCPEC, 2006; 1533-1536.

31. Meillaud F, Feltrin A, Dominé D, Buehlmann P, Phyton M, Bugnon G, Billet A, Parascandolo G, Bailat J, Faÿ S, Wyrsch N, Ballif C, Shah A. Limiting factors in the fabrication of microcrystalline silicon solar cells and microcrystalline/amorphous ("micromorph") tandems. Philosophical Magazine 2009; 89: 25992621.

32. Matsui T, Kondo M, Matsuda A. Origin of the improved performance of high-deposition-rate microcrystalline silicon solar cells by high-pressure glow discharge. Japanese Journal of Applied Physics 2003; 42: L901-L903.

33. Nakamura K, Youshida K, Takeota S, Shimizu I. Roles of atomic hydrogen in chemical annealing. Japanese Journal of Applied Physics 1995; 34(2A): 442-449.

34. Matsuda A. Growth mechanism of microcrystalline silicon obtained from reactive plasmas. Thin Solid Films 1999; 377(1-2): 1-6.

35. Terasa R, Albert M, Grüger H, Haiduk A, Kottwitz A. Investigation of growth mechanisms of microcrystalline silicon in the very high frequency range. Journal of Non-Crystalline Solids 2000; 226-269: 95-99.

36. Terasa R, Albert M, Bartha JW, Brechtel H, Kottwitz A. Time-resolved layer thickness behavior of microcrystalline and amorphous silicon samples after switching on a hydrogen/silane VHF plasma. Journal of Non-Crystalline Solids 2002; 299-302: 58-62.

37. Strahm B, Howling AA, Sansonnens L, Hollenstein Ch. Plasma silane concentration as a determining factor for the transition from amorphous to microcrystalline silicon in $\mathrm{SiH}_{4} / \mathrm{H}_{2}$ discharges. Plasma Sources Science and Technology 2007; 16: 80-89.

38. Strahm B, Howling AA, Sansonnens L, Hollenstein Ch, Kroll U, Meier J, Ellert Ch, Feitknecht L, Ballif C. Microcrystalline silicon deposited at high rate on large areas from pure silane with efficient gas utilization. Solar Energy Materials \& Solar Cells 2007; 91: 495-502.

39. Bugnon G, Feltrin A, Meillaud F, Bailat J, Ballif C. Influence of pressure and silane depletion on microcrystalline silicon material quality and solar cell performance. Journal of Applied Physics 2009; 105: 064507.

40. Feitnecht L, Freitas F, Bucher C, Bailat J, Shah A, Ballif C, Meier J, Spitznagel J, Kroll U, Strahm B, Howling AA, Sansonnens L, Hollenstein C. Fast growth of microcrystalline silicon solar cells on 
LP-CVD $\mathrm{ZnO}$ in industrial KAI PECVD reactors. Proceedings of the 21st EU-PVSEC, 2006; 16341636.

41. Fridman AA, Boufendi L, Hbid T, Potapkin BV, Bouchoule A. Dusty plasma formation: physics and critical phenomena. Theoretical approach. Journal of Applied Physics 1996; 79: 1303-1314.

42. Strahm B, Bartlome R, Feltrin A, Ballif C. Optical emission spectroscopy to diagnose powder formation in $\mathrm{SiH}_{4}-\mathrm{H}_{2}$ discharges. Proceedings of the SPIE, 2009; 7409: 74090E-74090E-9.

43. Bartlome R, Feltrin A, Ballif C. Infrared laser-based monitoring of the Silane dissociation during deposition of silicon thin film. Applied Physics Letters 2009; 94: 201501.
44. Kilper T, van den Donker MN, Grunsky D, Mück A, Schmitz R, Zastrow U, Rech B, Bräuer G, Klein S, Repmann T. Quantification of the influence of oxygen and nitrogen contamination on the performance of microcrystalline silicon solar cells. Proceedings of the 21st EU-PVSEC, 2006; 1738-1743.

45. Torres P, Meier J, Flückiger R, Kroll U, Anna Selvan JA, Keppner H, Shah A, Littelwood SD, Kelly IE, Giannoulès P. Device grade microcrystalline silicon owing to reduced oxygen contamination. Applied Physics Letters 1996; 69: 1373-1375.

46. Nasuno Y, Kondo M, Matsuda A. Key issue for the fabrication of high-efficiency microcrystalline silicon thin-film solar cells at low temperature. Japanese Journal of Applied Physics 2002; 41: 5912-5918. 